my subjects, the pathology of which disease I have worked at for the past five years, publishing several cases in the Transactions of the Pathological Society. My conclusions have been drawn from such work and ny lectures were illustrated by sections from the cases that had come under my notice. Except for a collection of other people's cases illustrated by reprints of their diagrams, published in THE LANCET of April last, I am unaware of any special work done by Mr. Roger Williams in connexion with this disease. The fact that, having published such a paper, he should now wish to pose as a pioneer in this branch of pathology is very astonishing. My ideas as to classification, which according to his letter I have had the "audacity to appropriate," are given in a paper of my own published some months before, 1 which communication is acknowledged by him. The justification of my statement that $\mathrm{Mr}$. Roger Williams has grouped together cases of duct papilloma and rillous cancer as growths of a perfectly innocent nature is easily proved from his paper. He says: "It will be gathered from the above description that these growths are of a perfectly innocent nature, though often multiple; they have no tendency to local infection, nor do they ever disseminate in the adjacent lymph glands" \&c. Now among these cases he includes one of mine which, with some warmth, he maintained at the Pathological Society was not one of villous cancer, as I considered, but innocent in its nature. ${ }^{2}$ Following up his opinion he acts on this and draws statistics from it. How correct he has been in his surmise may be seen, since this same case has recurred locally and infected the axillary lymph glands. Further comment on Mr. Williams' frivolous letter is unnecessary; the readers of THE LANCET may easily draw their own conclusions from a perusal of the two papers and from a consideration of the work done by each to try to elucidate this interesting question in breast pathology. I am, Sirs, yours faithfully,

Lambeth Palace-rd., July 26th, 1892. H. BeTHAM RoBINsoN.

\section{"CURES" FOR INEBRIETY.}

\section{To the Editors of THE LANCET.}

Sins,-It seems necessary to respect and maintain the professional rule against the use of secret remedies, but many of us do not see our way quite clearly as to the application of this rule. I have always refused to prescribe chlorodyne on the ground (1) that no necessity had been shown for using that nostrum; (2) that its popular use was enslaving and destructive. Here it seemed to me that the professional cule went in furtherance of the public good. But many eminent physicians have regularly prescribed this secret remedy. Are such men liable to be struck off the roll of the Royal College of Physicians? Despite urgent pressure from valued patients I refused to use Koch's tuberculin on the sround (1) that it was a secret remedy, (2) that to inoculate a patient's system with some derivative from tubercle was a proceeding of the gravest character. But, on Professor Lister making a visit of inspection at Berlin and reporting in your columns in favour of this secret remedy, I could no longer refuse to use it for patients who clamoured for it. Was I liable to be struck off the roll of the Members of the Royal College of Physicians for the use of that secret remedy? Recently I was asked by the Committee of the Church Army to watch and report upon some irreclaimable clrunkards whom the committee had sent from their rescue department to a home at Putney established by the "Anglo-American Gold-Cure Company, Limited." I visited these men regularly at Putney and watched the performance with as much interest as when, chairman of the Committee on Spiritualism, I watched the performances of the spiritualist professors and others who came before that committee. At this Putney home I have seen, I think, twelve real gutter drunkards-some sent by the Church Army Rescue Department; some sent from the wood-chopping sheds of the Salration Army Rescue Department; some sent by other benerolent rescue-workers in the slums of London. My rôle has been that of a passive and benevolent but observant pectator. I do not now propose to detail the cases because as yet (three months in all) time has not set its seal upon those results. But I should be dishonest or cowardly if I clid not confess that I have been deeply impressed by the

1 Transactions of the Pathological Society, rol. xlii., p. 229. 2 Ibid., vol. xli., p. 221. results of the treatment which I have watched upon these poor broken-down brothers and sisters.

The methods of treatment and the remedies used by the "Anglo-American Gold-Cure Company" are admittedly only a modification of those worked out by Dr. Keeley at Dwight. The physician who has worked out these modifications of Dr. Keeley's methods was formerly a helpless inebriate, who was taken by his wife (also a Doctor of Medicine) to Dwight, and who there was cured in three or four weeks. He has been in active, useful work ever since, and is now a very prosperous man. His inspiration, therefore, came from Dwight. On Dr. Keeley's recently visiting London I went into what evidence I could get as to his wonderful clinique of drunkards and morphia-men at Dwight, and I became convinced that "there must be something in it." I received a card from the Church of England Temperance Society for the meeting at the Westminster Town Hall and I went. Dr. Keeley was there. He kindly made my acquaintance as one of the physicians of the Temperance Hospital and I took him over that hospital. He then offered me unrestricted access to the Keeley home near the Marble Arch, and I have watched the results of his treatment and remedies upon the patients there. I have had the privilege of long conversations with Dr. Keeley and I am convinced that he knows more about the handling of drunkards and morphiamen than all the doctors I have ever met before. In fact, upon a subject which has for years worried and sickened me, I feel now that from Dr. Keeley I have obtained new germinal thought. I am convinced also that the results of Dr. Keeley's methods of treatment and remedies are altogether beyond anything that has hitherto been achieved by the profession in regard to the treatment of these narcomaniacs. In point of fact I last week recommended two lady patients who have scarcely been sober for years to go into Dr. Keeley's home. Will my now testifying to these convictions, and my confessing to these acts, make me liable to be struck off the roll of the College of Physicians? I am, Sirs, your obedient servant,

Dover.street, W., July, 1892.

JAMES EDMUNDS.

\section{Th the Editors of THE LANCET.}

SIRs, - It is quite true that I reserve for the present the details of my treatment for the crave due to the use of alcohol and narcotic alkaloids, and I submit to any comments which you may think proper to make upon that fact. But in other respects you have been misinformed and I am obliged to ask you to publish my reply.

2. As to my remedies, Dr. Kerr, in his speech (THE LANCE' p. 107), said that my remedy "was very dangerous and was compounded of a number of poisonous intoxicants." Yet a few minutes later Dr. Kerr produced "a careful analysis" (anonymous) which proved that my remedy contained nothing more poisonous than 27.55 per cent. of alcohol. It is not necessary for me to waste time in comment upon such crazy assertions.

3. Dr. Kerr's Society passed a unanimous resolution condemning the use of my remedy for inebriates, on the ground that it contained 27.55 per cent. of alcohol. Could anyone have more completely stultified his Society? My remedy is taken in teaspoonful doses in a wineglassful of water for three weeks only, precisely as any bottle of drops prescribed by any physician in London is taken. But such London drops, instead of containing 27.55 per cent. of alcohol, contrin always 57 per cent., and often a great deal more. In point of fact my remedr is a tincture containing just enough alcohol to prevent decomposition. As to Dr. Usher's speech, if he will let us understand exactly what he has to say by a letter in your columns I will answer him. The pink injection does not contain atropine. Dr. Usher is reported as having asserted that three leading physicians from the eastern states visited my institute at Dwight while he was there, and that "six weeks later all their friends received circulars intimaling that these gentlemen had been remarkable successes in the cure way." This statement is a sample of others that have been made. It is false. I ought to add that Dr. Usher merely stayed over one train at Dwiglet, a period of three hours and a half. My chemist is Mr. John R. Oughton. He was in Chicago on that day and Dr. Usher could not have seen him. The young man whom I sent to the treatment hall with Dr. Usher was an Irish bottle-washer. Our pharmacy is a very large one, containing 
a -cientific laboratory, and is as perfectly equipped as any chemical laboratory in the United States. Dr. Usher's object in seeing me personally was ostensibly to ascertain if he could buy of me the right to use my remedies in Australia and to open a Keeley Institute there.

4. I do not know what you, Sirs, would have said if I had sent you a letter asking you to come to my lecture at $\mathrm{St}$. James's Hall, and then, in order to get an audience, I had advertised that the Editors of THE LANCET had been invited to speak at the meeting. You would have denounced this as an impudent advertising trick. But this is precisely what Dr. Kerr did with my name. I request Dr. Kerr not again to put my name into his advertisements without having first obtained my permission.

5. As to the deaths which Dr. Kerr parades, they are as inconsequential as his other statements. Without now discussing these particular cases, I have only to demur to his innuendo. The veriest tyro in vital statistics will tell him that half-a-dozen deaths among 70,000 drunkards is an infinitesimal mortality. During the last thirteen years 70,000 drunkards and opium users have (from all parts of the world) come under the care of myself and my assistants. Among that procession of drunkards there have been some 2000 physicians. Of all those patients no one has ever sustained an injury at $\mathrm{my}$ hands or as a consequence of my remedies.

6. You have criticised the proceedings of the gentlemen who propose to found institutes in the United Kingdom for the cure of inebriates by means of my remedies and my methods. I have nothing whatever to do with those proceedings. Those proceedings are the acts of Englishmen, and those Englishmen, as I understand, intend to send communications of their own to some of their critics in reference to business matters. What I have to do is to vindicate my own professional position and to answer the charges which have been made against me and against my methods of treating my patients. The only thing which I did was to vindicate an eminent physician in Chicago who was thoroughly conversant with my methods of treatment and with the therapeutical action of my remedies upon inebriates, and to express the crinion that they would act wisely to retain the services of that gentleman as their medical director in England.

I am, Sirs, yours truly,

LESLIF E. KEELEY, M.D., LL.D.

Hotel Victoria, Charing Cross, July 26th, 1892.

** We have omitted the paragraph of our correspondent's letter numbered 1 , as it contains language the strength of which would probably in this country be deemed to be of a libellous character. Dr. Keeley's letter in no way removes our objections, and the objections of the profession, to the employment of secret remedies.-ED. $\mathbf{L}$.

\section{DENTISTRY AND WORKHOUSE CHILDREN.}

To the Editors of THE LANCET.

SIRs, - In your issue of July 16 th you mentioned under the above heading how the Strand board of guardians had recently appointed a qualified professiomal dentist to attend the children at their schools at Edmonton, and that the chirman remarked that this was the first appointment of the kind made by any metropolitan or provincial board of guardians, and took credit to the Strand board of guardians for initiating such a necessary and beneficial advance. May I le permitted to say that more than six years ago-viz., A yril 29th, 1886-the St. Pancras board of guardians on my recommendation appointed a professional qualified dentist practising in London to attend the children in their schools here, which he has continued to do ever since? When pressing this matter on the attention of the board I mentioned how a similar appointment had been made at the North Surrey district schools at Anerley and at the Lambeth schools with the approval of the Local Government Board.

I am, Sirs, yours truly,

J. ADAMs Clarke, Medical Officer.

St. Pancras Schools, Leavesden, King's Langley, July 25th, 1892.

** Mr. J. Bond, clerk to the Westminster guardians, also writes, saying "the guardians of the Westminster Union : ppointed a dentist to their school in the year 1886." - ED. L.

\section{THE CHOLERA IN PARIS.}

(From OUR SPECIAL CORREsPONDEsT.)

LAsT week I described the conflict of authority existing between the Prefect of Police and the Prefect of the Seine; and how the former authority, taking the bull by the horns, had constituted a Permanent Committee of Hygiene with a staff of medical inspectors. The object of this committee was to centralise the sanitary services with respect especially to disinfection and the removal of patients suffering from contagious diseases to the hospitals. So far so good; but the matter did not rest here. Formerly the public works for the town of Paris were all managed by M. Alphaud. Now that this great administrator is dead the necessity has arisen to divide the various services which he managed and pot experts at the head of each department. M. Sauton has submitted to the Municipal Council a project of reorganisation which was discussed on July 21st. Without entering into the detail of the project and the debate 1 may say that what affects the present epidemic is the fact that the Article No. 2, as amended, was adopted. The following is the text of this Article :-

Art. II. 'The Prefect (of the Seine) is invited to consti tute, at the Direction of Municipal Affairs, whose action shall be purely administrative, a central service of hygiene and salubrity of dwelling houses, which shall be attached to the services, whether administrative or technical, that relate to the hygiene of the dwellings forming part of the ancient Direction of Works. For this purpose the Director of Municipal Affairs shall be assisted by a General Inspector and a Commission composed of hygienists. The composition of this committee shall be ultimately decided according to the advice of the Municipal Council.'

The decree of the Prefect of Police forming a permanent committee of hygiene was issued on July 12th. On July21st the Municipal Council decided that the Prefect of the Seine shall also have a committee of hygiene and a staff of inspectors \&c. Of course some difference must be made between these two committees, and the difference rests on this fact, that the committee under the Prefecture of the Seine will only attend to the interior of honses, and there fore it is called a Central Service of Hygiene and Salubrity for Habitations. No sooner was this matter settled than an Inspector-General of Hygiene and Salubrity of Dwelling Houses was appointed, and Dr. A. J. Martin has been selected to fulfil this office. Certainly it would be difficult to make a better choice. No one has a wider practical experience of hygiene. In England Dr. A. J. Martin is a familiar figure. He was the Commissioner of the French Government for the French Section of the Health Exhibition held at South Kensington and was prominent at the recent International Congress of Hygiene which met in London.

At first sight it would appear as if the appointment of two committees, one under each of the rival Prefectures, would only add to the confusion actually prevailing. There is, nevertheless, every reason to hope that this will not be the case. The other day I had a good illustration of the manner in which the arrangement will work. There may be anta. gonism between the two Prefectures ; there is no antagonism between the well-known and prominent medical men and sanitary reformers who are battling for the cause of hygiene in France. Thus, when I went to congratulate Dr. A. J. Martin on his appointment, I found he was expecting a visit from Dr. Dujardin-Beammetz. Now Dr. Dujardin-Beaumetz is member of the Council of Hygiene attached to the Prefecture of Police. When something had to be done in conjunction with the Prefecture of the Seine, a clerk of the Prefecture of Police was told off to communicate the fact to a clerk of the Prefecture of the Seine. These clerks, it must be borne in mind, lead a most tedious, monotonous life. For want of something better to occupy their minds they develop a sort of patriotism in favour of their particular office or branch of the administration. This engenders extraordinary susceptibilities; and just as courtiers used to quarrel as to who should walk first in a royal procession, so the clerks of the Prefecture of Police quarrelled with the clerks of the Prefecture of the Seine as to who should fulfil certain functions. Such squabbles relieve the monotony of the bureaucratic life; but, as I mentioned last week, they have been so acute that it is supposed a life may have been lost because it was below the dignity of one adminis 